\title{
Histology and Histochemistry of the Flank Gland of the Indian Musk Shrew
}

\author{
M. BALAKRISHNAN \& K. M. ALEXANDER
}

\begin{abstract}
Balakrishnan M. \& Alexander K. M., 1977: Histology and histochemistry of the flank glands of the Indian musk shrew. Acta theriol., 22, 16: 241-249 [With 1 Table \& Plates XIV-XV].

Studies on the histology and certain aspects of histochemistry of the flank gland of the Indian musk shrew, Suncus murinus viridescens have been conducted. This gland is mainly comprised of: a) sebaceous glands which constitute the bulk and b) comparatively few sudoriferous glands located at the periphery. Histochemical observations revealed that this gland is deeply sudanophilic. No significant sexual dimorphism could be observed in the flank gland of the shrew. The secretion of the flank gland has been observed to be employed for active marking which was also not sexually dimorphic.

[Dept. Zool., Univ. Kerala, Kariyavattom 695581, Trivandrum, Kerala, India].
\end{abstract}

\section{INTRODUCTION}

Specialized skin glands have an ubiquitous distribution in mammals and recently considerable attention has been focussed on their behavioural significance (Q u a y, 1955; 1962; Myk y tow y c z, 1965; 1966a; b; c; Quay \& M üller-Schwarze, 1970; 1971). However, relatively very little is known about the skin glands of insectivores ( $\mathrm{L}$ in d e, 1907; J ohns on, 1914; Hamilt on, 1940; Pearson, 1946; Crowcr of t, 1957; Dryden \& Con a way, 1967; Mock \& K ivett, 1971; Bala$\mathrm{kr}$ ishnan \& Alexander, 1977). Recent investigations on ethology of shrews indicate that the secretions of their flank glands could have a marked influence on social interactions of these animals (B a la$\mathrm{krishnan}$ \& Alexander, 1975). The present report deals with a study on the histophysiology of the flank gland of the musk shrew, Suncus murinus viridescens and its possible ethological relevance.

\section{MATERIALS AND METHOD}

Shrews were trapped from the fields around the University Campus, Kariyavattom and brought to the laboratory. The sexes were identified and body weights were recorded. Fur from the flank gland and surrounding skin was carefully removed by a sharp blade after administering ether anaesthesia to adult healthy 
shrews of both sexes and measurements of the length and width of the gland were taken using a fine dividers and a centimeter scale. Later they were killed by an excessive ether anaesthesia, flank glands were quickly removed, blotted dry on a filter paper, cut into manageable strips and fixed in the following fixatives for histological and histochemical studies: a) Bouin's fluid, b) $10 \%$ formalin, c) ice-cold alcoholic picro-formol, d) ice-cold alcoholic silver nitrate and e) cold acetone ethanol mixture. Routine processing of these tissues fixed for histology and histochemical tests for protein, ascorbic acid, glycogen and alkaline phosphatase were carried out after $24-48$ hours, embedded in paraffin wax and sections were cut at $5 \mu \mathrm{m}$. Those tissues fixed for lipids were washed well after 24 hours embedded in gelatin and section were cut at $8-10 \mu \mathrm{m}$ on a Model CTD-International-Harris Cryostat at $-20^{\circ} \mathrm{C}$.

As for histological investigations, sections were stained with haematoxylin and eosin and with Mallory's triple stain. Micromeasurements were carried out in an Olympus binocular microscope employing a Leitz micrometer.

The histochemical studies were conducted employing Sudan black-B and fettrot for lipids, bromphenol blue for protein, PAS and Best's carmine techniques for glycogen, modified method of Bourne (Pearse, 1968) for ascorbic acid and modified calcium cobalt method (Pearse, 1968) for alkaline phosphatase. Routine processing of control sections were also carried out.

\section{RESULTS}

Morphologically, the region of flank gland is distinctly demarcated in both the sexes by its bulged nature and tuft of hairs. Data regarding the glandular size in both male and female shrews are given in Table 1. In male shrews, this gland had a mean length of $12.54 \mathrm{~mm}$, whereas in females it was $11.30 \mathrm{~mm}$ with the mean width of this gland in male and female shrews being $9.66 \mathrm{~mm}$ and $8.15 \mathrm{~mm}$ respectively. The thickness of the flank gland in male shrews varied from $1217-1998 \mu \mathrm{m}$, while it ranged from 1100 to $1674 \mu \mathrm{m}$ in the female shrews.

Histology: Figures 1-4 illustrate the histological features of the flank gland of the shrew, Suncus murinus viridescens. The glandular tissue was observed to be enveloped peripherally by the epidermis beneath which the papillary layer of the dermis is located exhibiting many hair follicles and well developed connective tissue extending into the deeper zones. The lateral and the lower aspects of the gland are encapsulated by a connective tissue layer. Beyond this, each of the secretory tubule has a thin connective tissue sheath.

The flank gland of $S$. viridescens is essentially comprised of highly developed sebaceous and enlarged sudoriferous glands. The former comprise the bulk of the gland, with the latter being localized mainly along the glandular periphery though not specifically confined to that region (Fig. 1). In fact, zonal differentiation between these two glandular tubules could not be discerned. There was no significant sexual dimorphism in the differential pattern of these secretory tubules. 
The ductal portion of the sebaceous gland and its union with an hair ollicle are shown in Figure 2. The typical cellular structure of the secretory portions of the well developed sebaceous flank gland of Suncus nurinus viridescens, is illustrated in Figure 3 (Pl. XIV).

The secretory tubules of the sebaceous glands are larger in size towards the interior with a diameter varying from 129-202 $\mu \mathrm{m}$. The epithelial vall of the tubule is comprised of 3-6 layers of cuboidal cells and gets proliferated at the region of the lumen wherein the secretion (holocrine) is stored. The secretory tubules proceed to the exterior by a narrow cuct of about $22 \mu \mathrm{m}$ in diameter which in its turn drains into the issociated hair follicle. No other special duct has been observed in conrection with the gland under study.

The sudoriferous glands are formed of highly enlarged, coiled glanduhr tubules composed of a single layer of cuboidal and columnar epithelial (ells (Fig. 4). The large central lumen is rather clear with the secretory naterials found either attached to the wall of the tubules on the inner

Table 1

Iata on the flank gland morphology of the shrew, Suncus murinus viridescens.

\begin{tabular}{lccccccc}
\hline Sex & $\begin{array}{c}\text { Number } \\
\text { of } \\
\text { animals }\end{array}$ & $\begin{array}{c}\text { Body } \\
\text { weight, } \\
\mathrm{g}\end{array}$ & $\begin{array}{c}\text { Length, } \\
\mathrm{mm}\end{array}$ & $\begin{array}{c}\text { Width, } \\
\mathrm{mm}\end{array}$ & $\begin{array}{c}\text { Thickness, } \\
\mu \mathrm{m}\end{array}$ & $\begin{array}{c}\text { Follicle } \\
\text { length, } \\
\mu \mathrm{m}\end{array}$ & $\begin{array}{c}\text { Follicle } \\
\text { width, } \\
\mu \mathrm{m}\end{array}$ \\
\hline Kale & 10 & $45 \pm 1$ & $12.54 \pm 0.3$ & $9.66 \pm 0.2$ & $1857 \pm 101$ & $1519 \pm 121$ & $173 \pm 16$ \\
Iemale & 10 & $28 \pm 1$ & $11.30 \pm 0.02$ & $8.10 \pm 0.02$ & $1521 \pm 64$ & $1307 \pm 53$ & $157 \pm 7$ \\
\hline
\end{tabular}

Iata analysed statistically; means with \pm standard errors are given.

surface as a thin layer or found scattered in the lumen. The sudoriferous clands are apocrine in nature.

Histochemistry: Figures 5-10 illustrate the histochemical features of the flank gland of the musk shrew, S. viridescens.

It could be noted that the flank gland tissue in general is deeply sudanophilic. The epithelial cells of the secretory tubules are filled with lpid droplets which are extruded to the lumen of each tubule whereat a large accumulation of lipophilic secretory material could be observed (Figs. 5 \& 6). The ducts of these tubules as well as the hair follicles vere also filled with the lipophilic materials. Relatively, the lipid concentration was more markedly localized in those secretory tubules found in the deeper zones of the gland.

The secretory tubules of the flank gland were lightly stained with bromphenol blue. The protein concentration was lower in the flank gland tssue as compared to the surrounding skin region. The intensity of protein was relatively higher in the peripheral aspects of each secretory tibule (Fig. 7, Pl. XV). 
Studies employing PAS as well as Best's carmine techniques revealed positive reactions in certain specific regions of the flank gland (Fig. 8). The outer epidermis and the papillary layer of the dermis exhibited a comparatively higher amount of glycogen. This was found to be in conformity with the skin of the neighbouring region. The connective tissue sheath of the secretory tubule was also rather rich in glycogen. Further, the connective tissue sheath of each tubule could distinctly be demarcated by virtue of its PAS and Best's carmine positive nature. The epithelial wall of the secretory tubules also exhibits some granular cytoplasm with positive reaction towards these stains. These granules were selectively localized near the basement sheath. The negative reaction of this region in the diastase treated control slides suggest that these are glycogen granules. The lumina were found to be devoid of any $P A S$ positive material.

A distinctive silver nitrate positive reaction in the secretory tubules has been demonstrated in Figure 9. Larger amounts of ascorbic acid were localized towards the interior of the tubules just as in the case of lipids. The connective tissue sheath, epidermis and dermal layers were totally devoid of ascorbic acid. All lipid positive areas could be observed to be stained black with silver nitrate.

Alkaline phosphatase was localized in large amounts in the secretory epithelial cells, mostly on the outermost layer of each tubule (Fig. 10). None of the other areas exhibited any significant reaction for this enzyme.

\section{DISCUSSION}

The flank gland of $S$. $m$. viridescens is comprised of two types of glandular secretory tubules: the sebaceous and sudoriferous, with the latter being comparatively few in number and are either intermingled with the sebaceous glands which constitute the bulk of the flank gland, or found located at the periphery. This is in contrast to the report on flank glands of the short tailed shrew, Blarina brevicauda (P e a r s on, 1946) wherein the sweat glands comprised the principal elements. Nevertheless, with regard to most of other histological features, the flank gland of $S$. $m$. viridescens compare favourably with general pattern of the sebaceous skin glands of other mammals investigated ( $\mathrm{u}$ a $\mathrm{y}$, 1962; 1968; Qua y \& M üller-Schwarze, 1970). Despite the earlier reports on a zonal differentiation in some mammalian skin glands $(Q \mathrm{u}$ a y \& $\mathrm{M} \ddot{\mathrm{u}} \mathrm{ll}$ e $\mathrm{r}-\mathrm{S} \mathrm{chw}$ arze, 1970) with the sudoriferous glands occuring at the deeper and sebaceous glands in the upper zones, the data obtained for $S$. $m$. viridescens do not suggest such a delineation.

The errector pili muscles, functioning to errect the hair and to eject 
the secretion from the glands $(\mathrm{Q} u$ a $y, 1955 ; 1959)$ have not been observed in the flank gland tissue of musk shrews. In fact similar absence of these smooth muscle bundles has been reported in the flank glands of Neofiber, Clethrionomys and in Synaptomys (Quay, 1968). Further, since the secretions of the flank glands are transferred to objects by active marking (Balakrishnan \& Alexander, 1975), quite probable the absence of errector pili muscles may be selective at the glandular region.

Since the secretory products of the flank gland of $S . m$. viridescens are highly sudanophilic, lipids constitute a large proportion of the secretory material. Biochemical assay of flank gland tissue and secretions have revealed a relatively very high concentration of lipids in these tubules than those of control skin samples (B a lakrishnan \& A lexander, 1974). The occurence of large amounts of the sudanophilic materials in the centre of the secretory tubules indicate their probable storage in the lumen of the tubule.

Histochemical localization of protein revealed that the flank gland tissue in general had much lower intensity of protein than the surrounding skin and the muscle beneath. Biochemical assays have also confirmed this inference (Balakrishnan \& Alexander, 1974).

The present study revealed a relatively sparse distribution of PAS positive cells in various parts of the flank gland of $S . m$. viridescens. Similar observations have been reported for the sudoriferous glands of the angulus oris of microtine rodents ( $\mathrm{u}$ a y, 1962).

Ascorbic acid has been known to be linked with lipid and carbohydrate metabolism (Banerjee \& Ghosh, 1947; Banerjee \& $\mathrm{Ganguli}$, 1962) and the higher concentration of ascorbic acid within the flank gland is suggestive of its high metabolic activity. The present study has also indicated the presence of an appreciable greater concentration of ascorbic acid in those glandular zones possessing a relatively higher accumulation of lipids. The comparatively more intense reaction for alkaline phosphatase at the basal epithelial layer of the secretory tubules could be correlated to their secretory potential.

The scent glands have been reported to be sexually dimorphic in many species and in certain cases seasonal and geographic variations were also recorded (Q u a y, 1968; 1971). The flank gland of European shrews have been observed to be sexually dimorphic with those of breeding males being darker than the surrounding flesh with prominent blood vessels whereas in females and juveniles they are inconspicuous, bruised looking areas without enlarged blood vessels ( $\mathrm{Cr}$ ow c r of t, 1957). The ventral and side glands of Blarina brevicauda were well developed in breeding males, non-breeding males and in females but were poorly developed du- 
ring estrus, pregnancy and lactation ( $\mathrm{P}$ e a r s o $\mathrm{n}, 1946)$. The present study on the flank gland of $S$. $m$. viridescens indicates that there is no significant sexual dimorphism either for the morphological or histophysiological aspects. The flank gland weight - body weight ratio was also found to be similar in both sexes (B a lakrishnan \& A l exander, unpubl.).

The functional significance of the flank gland of shrews has been diversely discussed ( $\mathrm{Pe}$ a r son, 1946; Crow croft, 1957). The development of the flank gland of Blarina has been observed to be controlled by sex hormones and it was further demonstrated that a cyclical activity in relation to the sexual cycle exists in females (P e a r son, 1946). However, Dryden \& Con aw a y (1967) have reported that the secretion of the side gland of Suncus murinus has only apparently little effect on human olfaction, and that the musky odour of this species originate from the coiled apocrine glands situated in the postauricular region in both the sexes (Dryden \& C on a w a y, 1967; B a lakris hn an \& A lexander, unpubl.). Nevertheless, it may be mentioned herein that the chemical compounds contained in the secretion of the flank gland of shrews need not necessarily be effective on human sensory systems.

Recent behavioural studies had revealed that shrews of both sexes would often mark the sides of the cbservation tank and objects placed therein by secretions of the flank glands (Balakrishnan \& Alexa n d e r, 1975). No sexual dimorphism has been observed in such a marking. In male shrews, flank gland marking was almost eliminated by 4 weeks after castration and restored on treatment with either androgen or estrogen in effective doses (Balakrishnan \& Alexander, 1976). Further investigations on the role of the secretions of this gland in social interactions of $S . m$. viridescens are in progress.

Acknowledgements: We are grateful to late Prof. K. K. N a y a r, Head of the Department of Zoology, University of Kerala for constant encouragement and for critically reading the manuscript. Our thanks are also due to Mr. T. I. J a c o b for assistance in photomicrography. This work had been supported by a research grant from the University Grants Commision, New Delhi.

\section{REFERENCES}

1. Balakrishnan M. \& Alexander K. M., 1974: Studies on certain aspects of physiology and biochemistry of the flank gland of the Indian musk shrew, Suncus murinus viridescens (Blyth). Paper presented in the $3 \mathrm{rd}$ Annual Conf. Ethol. Soc. India, Bangalore.

2. Balakrishnan M. \& Alexander K. M., 1975: Role of androgen on marking of the musk shrew, Suncus murinus viridescens (B $1 \mathrm{yth}$ ). Bull. Ethol. Soc. India, $1: 1-6$.

3. Balakrishnan M. \& Alexander K. M., 1976: Hormonal control of 
marking behaviour of the male musk shrew, Suncus murinus viridescens (B i y t h). Horm. Behav. 7: 431-440.

4. Balakrishnan M. \& Alexander K. M., 1977: Specialized mucocutaneous junction glands of the Indian musk shrew. Acta theriol. 22, 15: 231-240.

5. Banerjee S. \& Ganguli N. C., 1962: Metabolic studies on scorbutic guinea pigs. 2. Hepatic glycogen synthesis in vitro and vivo. J. Biol. Chem., 237: $14-18$

6. B a nerjee S. \& Gosh N. C., 1947: Relation of scurvy to glucose tolerence tests, liver glycogen and insulin content of pancreas in guinea pigs. J. Biol. Chem., 168: 207-211.

7. Crowcroft P., 1957: The life of the shrew. Max Reinhardt: 1-166. London.

8. Dryden G. L. \& Conaway C. H., 1967: The origin and hormonal control of scent production in Suncus murinus. J. Mamm., 48: 420-428.

9. Hamilton W. J. Jr., 1940: The biology of smoky shrew (Sorex fumeus fumeus Miller). Zoologica, 15: 473-492.

10. Johns on S., 1914: Über die Seitendrüsen der Soriciden. Anat. Anz., 46: $139-141$.

11. Linde A. C., 1907: Der Bau der Soriciden und ihre Beziehungen zu anderen Säugetieren. Morphol. Jahhrb., 36: 463-514.

12. $\mathrm{Mock}$ O. B. \& Kivett V. K., 1971: Observations on the reproductive behaviour of the least shrew. Amer. Zool., 11: 618.

13. Mykytowycz R., 1965: Further observations on the territorial function and histology of the submandibular cutaneous (chin) glands in the rabbit, Oryctolagus cuniculus (L.). Anim. Behav., 13: 400-412.

14. Mykytowycz R., 1966a: Observations on odoriferous and other glands in the Australian wild rabbit, Oryctolagus cuniculus (L.) and the hare, Lepus europaeus P. I. Anal gland. CSIRO Wildlife Res., 11: 11-29.

15. Mykyt ow ycz R., 1966b: Observations on odoriferous and other glands in the Australian wild rabbit, Oryctolagus cuniculus (L.) and the hare, Lepus europaeus P. II. The inguinal glands. CSIRO Wildlife Res., 11: 49-64.

16. Mykytowycz R., $1966 \mathrm{c}$ : Observations on odoriferous and other glands in the Australian wild rabbit, Oryctolagus cuniculus (L.) and the hare, Lepus europaeus P. III. Harder's lachrymal and submandibular glands. CSIRO Wildlife Res., 11: 65-90.

17. i y k y tow ycz R., 1970: Role of skin glands in mammalian communication. [In Eds. Johnston J. W. Jr., Moulton D. G. \& Turk A. »Advances in Chemoreception, 1. Communication by Chemical Signals «]. 327-360. AppletonCentury-Crofts, New York.

18. P e a r s e A. G. E., 1968: Histochemistry - Theoretical and Applied. Churchill, 1: $\mathrm{X}+1-998$. London.

19. Pearson O. P., 1946: Scent glands of the short-tailed shrew. Anat. Rec., 94: $615-625$.

20. Quay W. B., 1955: Histology and cytochemistry of skin gland areas in the caribou Rangifer. J. Mamm., 36: 187-201.

21. Quay W. B., 1959: Microscopic structure and variation in the cutaneous glands of the deer, Odocoileus virginianus. J. Mamm., 40: 114-128.

22. Quay W. B., 1962: Apocrine sweat glands in the angulus oris of microtine rodents. J. Mamm., 43: 303-310.

23. Qua y W. B., 1968: The specialized posterolateral sebaceous glandular regions in Microtine rodents. J. Mamm., 49: 427-445. 
24. Q u a y W. B., 1971: Geographic variation in the metatarsal gland of the whitetailed deer (Odocoileus virginianus). J. Mamm., 52: 1-11.

25. Quay W. B. \& Mülle r-Schwarze D., 1970: Functional histology of integumentary glandular regions in black-tailed deer (Odocoileus hemionus columbianus). J. Mamm., 51: 675-694.

26. Quay W. B. \& M üller-Schwarze D., 1971: Relations of age and sex to integumentary glandular regions in rocky mountain mule deer (Odocoileus hemionus hemionus). J. Mamm., 52: 670-685.

Accepted, March 3, 1976.

M. BALAKRISHNAN i K. M. ALEXANDER

\section{HISTOLOGIA I HISTOCHEMIA GRUCZOEOW BOCZNYCH SUNCUS MURINUS VIRIDESCENS}

\section{Streszczenie}

Przeprowadzono badania histologiczne i w pewnych aspektach histochemiczne gruczołów bocznych Suncus murinus viridescens (Tabela 1). Gruczoły te składają się głównie z: a) gruczołów łojowych, tworzących przeważającą część (Ryc. 1-3) i b) stosunkowo niewielu gruczołów potowych, zlokalizowanych peryferyjnie (Ryc. 4). Badania histochemiczne wykazały, że gruczoly te są wyraźnie sudanofilne (Ryc. 5-10). Nie obserwowano istotnego dymorfizmu płciowego gruczołów bocznych. Wykazano, że sekrecja gruczołów bocznych jest używana do aktywnego znakowania u obu płci. 


\section{EXPLANATION OF PLATES XIV-XV}

\section{Plate XIV}

Fig. 1. Cross section of the flank gland of the shrew showing the predominantly sebaceous and a few sudoriferous tubules. Haematoxylin and eosin, $40 \times$.

Fig. 2. The ducts of the sebaceous secretory tubules of the flank gland open towards the exterior through the associated hair follicle. Haematoxylin and eosin, $100 \times$.

Fig. 3. Structure of intact sebaceous secretory tubules of the gland. Haematoxylin and eosin, $400 \times$.

Fig. 4. Enlarged view of the apocrine sudoriferous tubules of the flank gland. Haematoxylin and eosin, $400 \times$.

Abbreviations: SE, sebaceous gland; SU, sudoriferous gland.

\section{Plate XV}

Fig. 5 \& 6. The secretory tubules stained deeply with Sudan black-B with a greater intensity towards the interior of each tubule revealing the lipophilic nature of the secretory material. The lipophilic secretory materials could also be seen in the tubular ducts leading towards the exterior. $100 \times$.

Fig. 7. The flank gland is fairly stained for protein with bromphenol blue. The intensity is comparatively higher in the outer layers of each sebaceous secretory tubules. $100 \times$.

Fig. 8. The connective tissue sheath of the secretory tubules is well stained for glyogen with PAS. Some glycogen granules could also be seen in the secretary epithelial cells. $100 \times$.

Fig. 9. Showing nitrate positive reaction of the secretory tubules of the flank gland. Ascorbic acid could be seen in higher concentration towards the interior of each secretory tubule wherein the glandular secretion is accumulated. $100 \times$.

Fig. 10. Alkaline phosphatase activity concentrates mainly on the outermost epithelial layer of each secretory tubule.

Abbreviations: ITC, interglandular connective tissue; SD, sebaceous gland duct; $\mathrm{SE}$, sebaceous gland. 

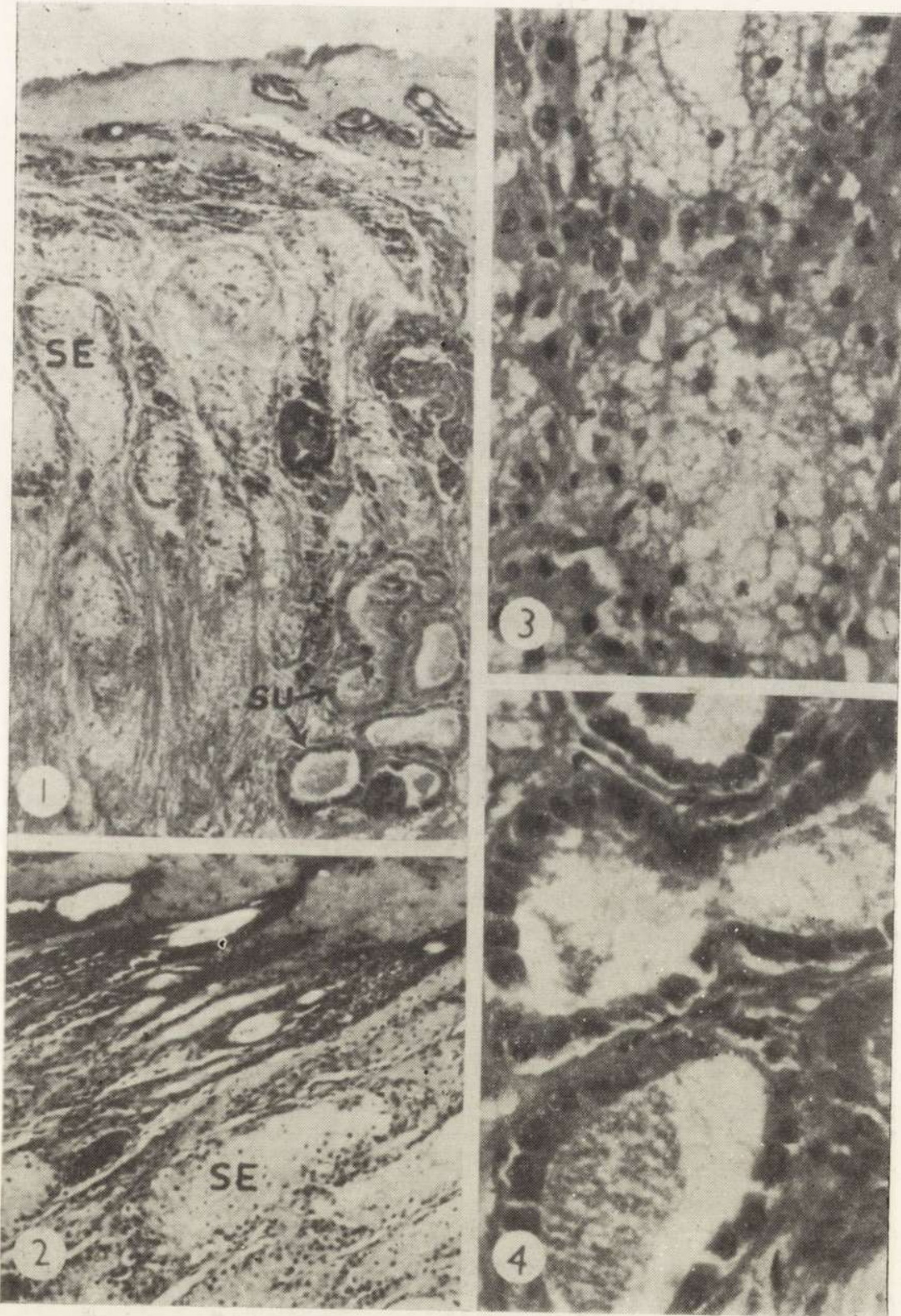

M. Balakrishnan \& K. M. Alexander auctores phot. 

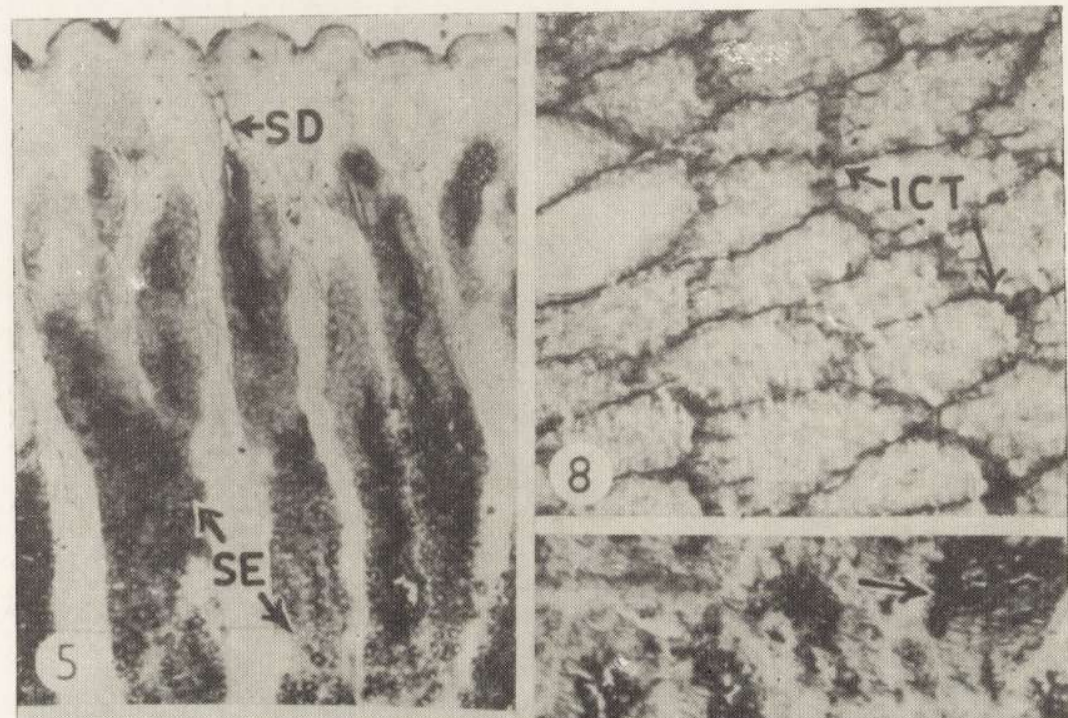

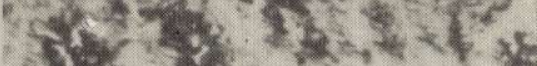
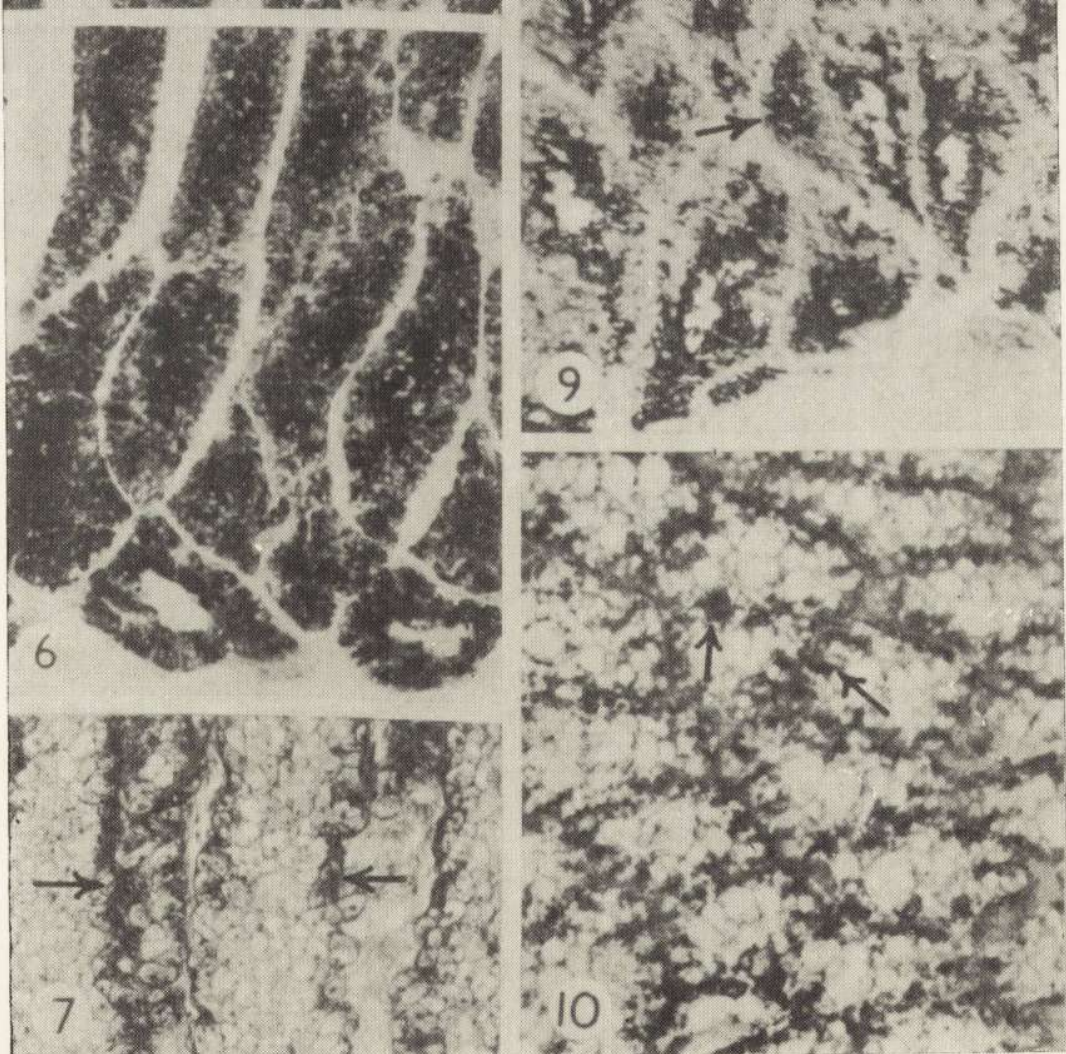

M. Balakrishnan \& K. M. Alexande

auctores phot. 